\title{
Effects of Sucrose (Sugar) as Inoculant on Physical Quality, Fermentation Profile and Relative Feed Value of Alfalfa Silage at Different Ensiling Time
}

\author{
Sükroz.(Şeker) Inokulantının Farklı Silolama Dönemlerindeki Yonca Silajinın Fiz̨iksel Kalitesi, Fermantasyon Profili ve \\ Nispi Yem Değeri Üzerine Etkisi
}

\section{Hıdır GÜMÜŞ*}

Burdur Mehmet Akif Ersoy University, Faculty of Veterinary Medicine, Department of Animal Science and Animal Nutrition, Burdur, Turkey

\begin{abstract}
This study was conducted to determine effects of sucrose (sugar) addition on physical quality, fermentation profile and relative feed value of alfalfa silage at different ensiling time. Silage quality was evaluated based on inoculant supplementation (C; no additive and S: sucrose additive) and four ensiling periods (7, 14, 30 and 60 days). The color and structure scores were unchanged but the smell score increased significantly by sucrose inoculant. Sucrose supplementation significantly decreased $\mathrm{pH}$ value in comparison to the control group. Significant change in Flieg point of alfalfa silage was observed between the groups. Relative feed value significantly increased in the sucrose group at $\mathrm{d} 7$ and 14 of ensiling, but remained unaffected at $\mathrm{d} 30$ and 60 of ensiling. As a result, addition of sucrose improved silage quality at different fermentation time.
\end{abstract}

Keywords: Alfalfa silage, Silage quality, Sucrose.

Öz: Bu çalışma, sükroz (şeker) ilavesinin farklı fermantasyon zamanlarda yonca silajının fiziksel kalite, fermantasyon profile ve nispi yem değerleri üzerine olan etkilerini belirlemek üzere yapılmıştır. Silaj kalitesi iki grup (C: katkısız; S: şeker ilaveli) ve dört farklı silolama zamanı (7, 14, 30 and 60 günler) olarak değerlendirilmiştir. Sükroz ilavesi ile koku ve strüktür skoru etkilenmemiş ancak koku skoru önemli düzeyde artmıştır. Kontrol grubu ile karşılaştırıldığında sükroz ilavesi ile $\mathrm{pH}$ değeri önemli düzeyde azalmıştır. Gruplar arasında Flieg puanın değişim önemli bulunmuştur. Nispi yem değeri sükroz grubunda silolamanın 7 ve 14. gününde önemli düzeyde artmış, ancak silolamanın 30 ve 60 . günlerinde etkilenmemiştir. Sonuç olarak, sükroz ilavesi farklı zamanlarda silaj kalitesini iyileştirmiştir.

Anahtar Kelimeler: Yonca silajı, Silaj kalitesi, Sükroz..

*Corresponding author : Hidır GÜMÜŞ e-mail : hgumus@mehmetakif.edu.tr

Geliş tarihi / Received : 19.11.2021 Kabul tarihi / Accepted: 08.12.2021

\section{Introduction}

Alfalfa (Medicago sativa L.) is a perennial plant and can supply green fodder continuously for 4-5 years from the same sowing. Alfalfa is flavorfully consumed by all kinds of livestock, since it yields nutritious and palatable green fodder, providing with 16-25\% crude protein (with $72 \%$ digestibility) and $20-30 \%$ fiber. It is naturally high in many essential minerals and vitamins, including; calcium (1.5\%), magnesium, potassium, iron, A, D, E, K, and B vitamins (Patra and Paul, 2019). According to the Turkish Statistical Institute, an average of 19.290 million tons of alfalfa green hay were produced in 2020 in Turkey (TUIK, 2020).
Alfalfa hay or silage is used in ruminants rations as a forage and it is important for the animal nutrition because of its high protein value (Aktürk and Gümüş, 2020). However, the protein value of alfalfa hay can decrease in the production, transport and storage processes (Gao et al., 2021). Due to the irregular rainfall, the wilting of legumes such as alfalfa hay, clover hay, trefoil hay etc., has become gradually difficult (Unal et al., 2012); therefore, making of alfalfa silage is an alternative method. Ensiling is a natural fermentation process of forage conservation to improve the nutritional value and extend the storage time (Ni et al., 2017). During this process, water-soluble carbohydrates (WSC) are converted into lactic acid (LA) via 
epiphytic lactic acid bacteria (LAB) resulting in a decline of $\mathrm{pH}$ (Yan et al., 2019). It is difficult to preserve quality of alfalfa silage due to its high protein content, greater buffer capacity and quite low sugar content (Ergin and Gümüş, 2020). Silage additives such as glucose, sucrose, and molasses have been used to decrease $\mathrm{pH}$ level that increased the number substrates for the growth of lactic acid bacteria $(\mathrm{LAB})$ as well as improved lactic acid concentration in the silage ( $\mathrm{Li}$ et al, 2014). This study aimed to examine the effects of sucrose (sugar) addition on physical quality, fermentation profile and relative feed value of alfalfa silage at different ensiling time.

\section{Materials and Methods}

The study was conducted at the Department of Animal Nutrition and Nutritional Diseases, Faculty of Veterinary Medicine, Burdur Mehmet Akif Ersoy University, located at $36^{\circ} 53^{\prime}$ North latitude and $30^{\circ} 53^{\prime}$ East longitude and $950 \mathrm{~m}$ above sea level. Burdur is the transition region in the inner part of the western Mediterranean. The experiment was conducted in a completely randomized design using two experimental groups as CON (control), with no inoculants; S (Sucrose), with 3\% sucrose as an inoculant (calculated based on the fresh weight of alfalfa). The inclusion levels of sucrose inoculant were based on a proper review of the existing literature. Following harvesting, the fresh alfalfa samples were chopped into small pieces $(\sim 1.5-2 \mathrm{~cm})$ by pruning shears for ensiling and the sucrose was applied to fresh alfalfa in the plastic basin. About $900 \mathrm{~g}$ of chopped alfalfa (fresh weight) was compressed by hand into a 1-L jar (100 mm diameter $\times 170 \mathrm{~mm}$ height). A total of 10 jars (5 jars per experimental group) were prepared and stored at ambient temperature (16 \pm $\left.2^{\circ} \mathrm{C}\right)$. Five silos from each group were opened for the analysis of physical quality (smell, color, structure of alfalfa silage), fermentation quality ( $\mathrm{pH}$ and Flieg point), nutritive value (DDM, DMI, RFV) on 7, 14, 30, and $60 \mathrm{~d}$ of ensiling. Physical quality analysis was assessed by using DLG scoring system (DLG, 1997). Each alfalfa silage samples were carefully opened and scored by 3 experts in terms of colour point (0-2), structure point (0-4), and scent point $(0-14)$ of the silage. According to score; silage was divided into the quality classes as Excellent (16-20 points); Good (10-15); Mid (5-9), and too bad (0-4). For the assessment of $\mathrm{pH}$ value, a $25 \mathrm{~g}$ fresh silage sample was blended with $100 \mathrm{ml}$ distilled water in a mixer for 4-5 min and filtered through a cheesecloth. The $\mathrm{pH}$ value was measured with a glass electrode $\mathrm{pH}$ meter (ECPlaza, Guro-gu, Seoul, Korea). Fleig point (Dong et al., 2017) was calculated by using $\mathrm{pH}$ and DM values of alfalfa silage at different days of ensiling with the following equation: Flieg's point $=220+$ $(2 \times \mathrm{DM}-15)-(40 \times \mathrm{pH})$. Digestible dry matter $(\mathrm{DDM})$ was determined by using ADF content of alfalfa silage $[\mathrm{DDM} \%=88.9-(0.779 \times \mathrm{ADF} \%)]$. Then dry matter intake (DMI) was measured by using NDF content of alfalfa silage $[\mathrm{DMI} \%=120 / \mathrm{NDF} \%)]$. Relative feed value was calculated (Redfarn and Zhang, 2014) by using $\mathrm{DDM}$ and DMI $[\mathrm{RFV}=\mathrm{DDM} \% \times \mathrm{DMI} \% \mathrm{x}$ 0.775]. The statistical analyses were conducted to the International Business Machines (IBM) for the Social Sciences (SPSS), version 22 (IBM, SPSS Statistics, 2022). The data were analyzed by independent-samples t-test to determine the effects of sucrose (sugar) addition on physical quality, fermentation profile and relative feed value of alfalfa silage at different fermentation time. The level of significance was taken as $\mathrm{P}<0.05$ (Dawson and Trapp, 2001).

\section{Results}

The smell score of silage was affected $(\mathrm{P}<0.05)$ by sugar inoculant at $\mathrm{d} 14,30$ and 60 except at $\mathrm{d} 7$ of ensiling. Colour score of silage remained unaffected all treatments $\mathrm{d}$ of ensiling $(\mathrm{P}<0.05)$. Structure score of silage was not affected $(\mathrm{P}>0.05)$ by sucrose inoculant regardless of the days. The total score of silage was significantly increased by sucrose addition at $\mathrm{d} 14,30$ and 60 of ensiling, but it was not affected at $\mathrm{d} 7$ of ensiling (Figure 1). The quality of alfalfa silage treated with sucrose was determined as 'excellent' all days. It was defined on $7^{\text {th }}, 30^{\text {th }}$ and $60^{\text {th }}$ days as "excellent", but on $14^{\text {th }} \mathrm{d}$ as "good". There was a significantly different effect $(\mathrm{P}<0.01)$ between groups for silage $\mathrm{pH}$. The $\mathrm{pH}$ value was in parallel decreases in all silages during the fermentation. Regardless of the days, the $\mathrm{pH}$ value was lower in the sucrose group in 
comparison to the $\mathrm{CON}$ group. Irrespective of the days, sugar additives remarkably increased $(\mathrm{P}<0.01)$ the Flieg point due to the increases in $\mathrm{DM}$ and decreases in $\mathrm{pH}$. At the end of the experiment, Flieg point of silage in the $\mathrm{CON}$ and
S group were 25.97 and 76.52 , respectively (Figure 2). At $\mathrm{d} 7$ and 14 of ensiling, RFV was significantly higher in silages prepared with sugar inoculant, but unaffected at d 30 and 60 of ensiling (Figure 3).

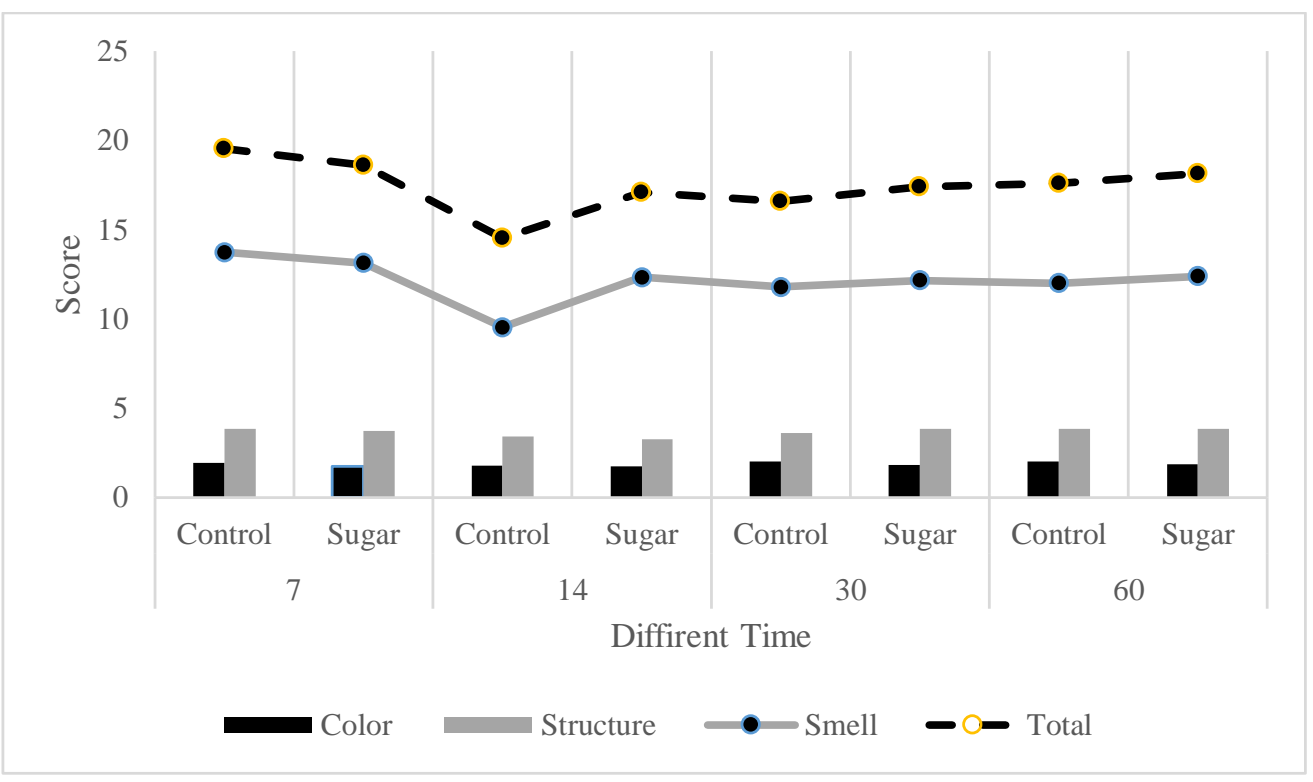

Figure 1. Color, structure, smell and total score of alfalfa silage

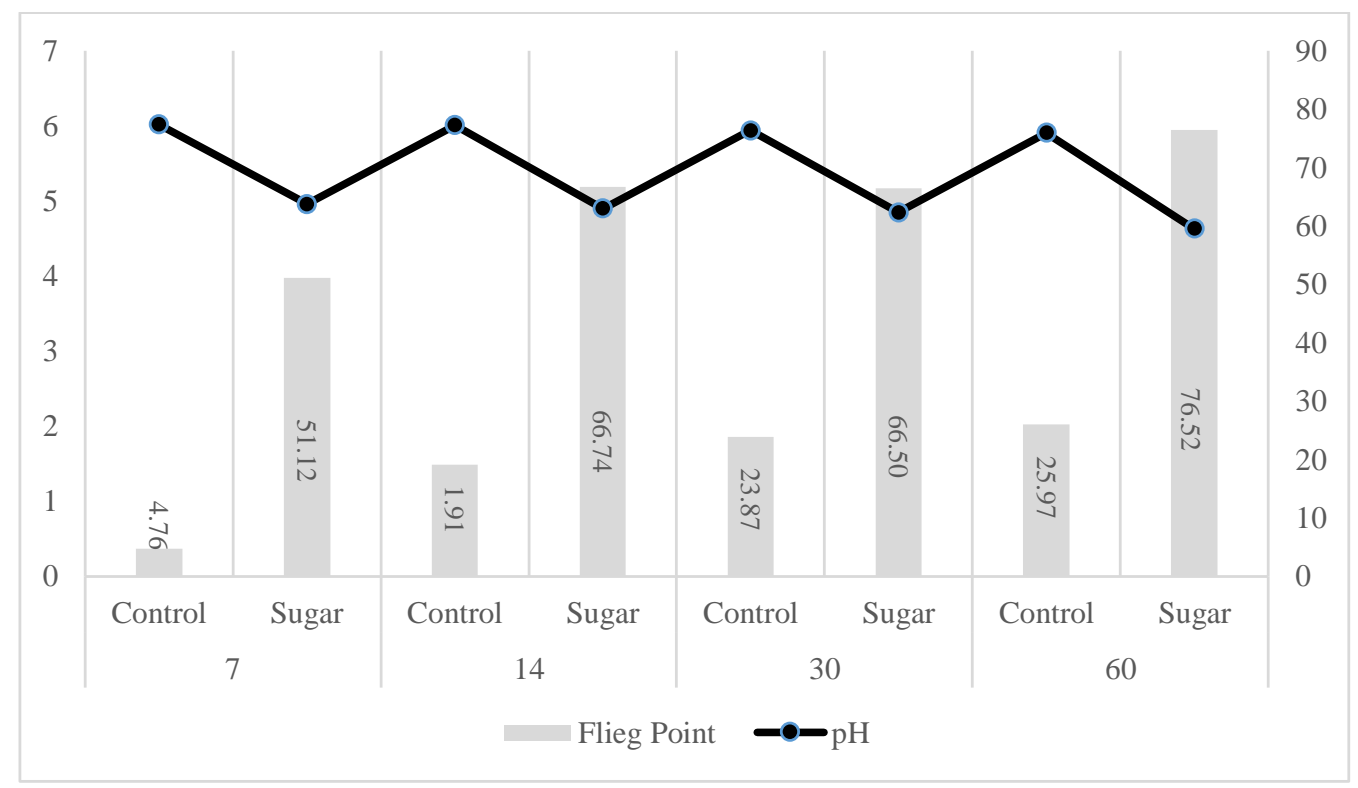

Figure 2. Flieg point and $\mathrm{pH}$ value of alfalfa silage 


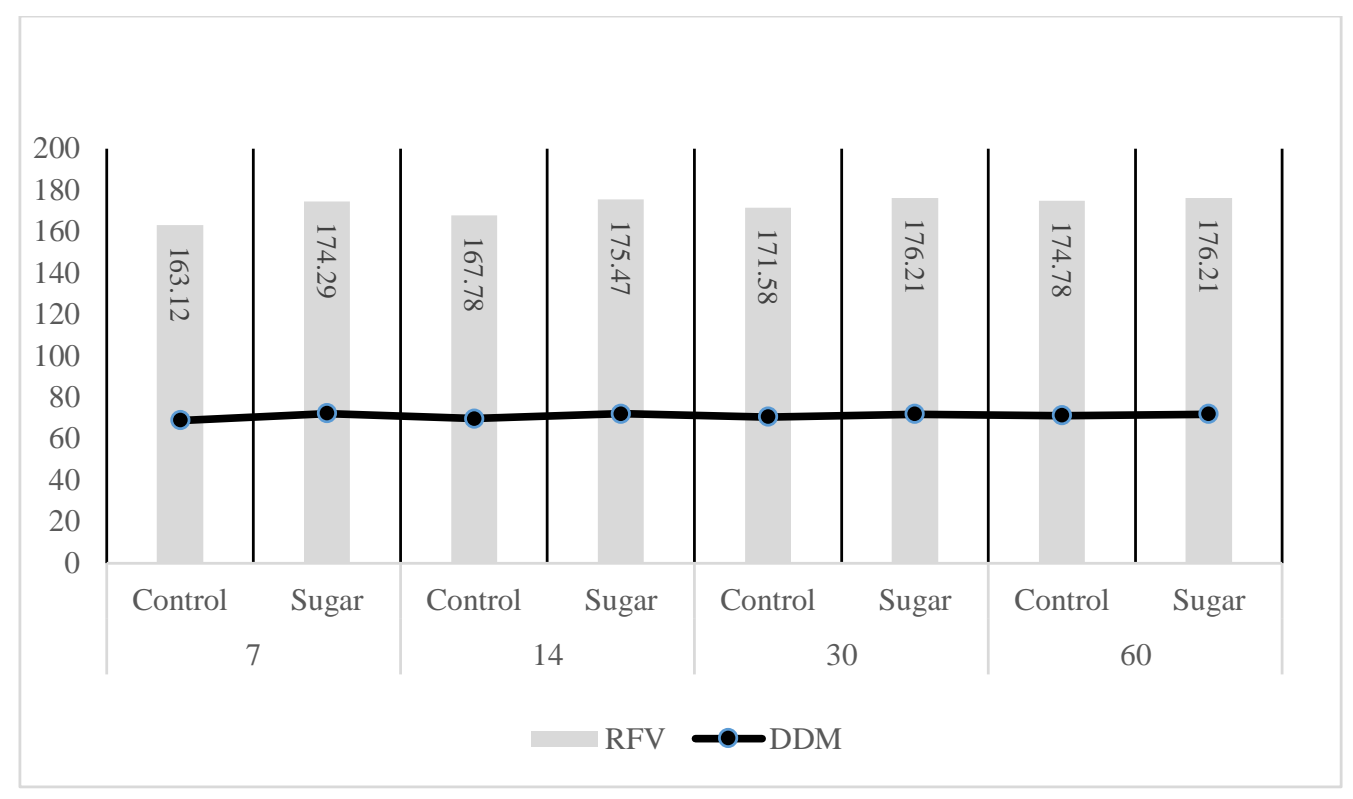

Figure 3. Relative feed value and digestibility dry matter of alfalfa silage

\section{Discussion}

Silage making is a significant technique in animal nutrition and it allows for longer storage time of forage. The assessment of smell, color, and structure score of silages are the best simple methods to evaluate the physical quality of silage during the fermentation process. This evaluation system has been commonly used for years in silage because it is an inexpensive and quick method (Zhao et al., 2019). Open green color, aromatic scent, such as bouquet and good structure, are desired in a high-quality silage (Muck et al., 2018). In the present study, smell score of alfalfa silage was significantly improved by sucrose inoculant throughout the ensiling period (Figure 1). Ergin and Gümüş (2020) stated that LAB inoculant significantly increased the smell score at $\mathrm{d} 60$ of ensiling. Turan and Önenç (2018) stated that no change in smell score of alfalfa silage was observed between cumin essential oil supplemented and unsupplemented silages. The smell score of silage ranged from 12.75-14.00 point (Topçu and Özkan, 2021). Color and structure score of alfalfa silage remained unaffected irrespective of the days (Figure 1). Also, the mean value of color score is in accordance with those verified in other silage study by addition sugar under similar conditions of the current study, where the values ranged from 1.74 and 2.00 point (Gümüş et al., 2020). Addition of sucrose did not affect the structure score. The findings of this study were in agreement with results of previous studies conducted on alfalfa silage (Turan and önenç, 2018; Ergin and Gümüş, 2020) and lenox silage (Gümüş et al., 2020). As expected, the increase in the total score in the sucrose-supplemented silages may be associated with the higher smell score. Gümüş et al. (2020) also reported similar finding for total score in silages with treated sucrose. Silage quality depends on certain factors such as forage and inoculant type, environmental temperature, nutritive value, and type of silage (Yan et al., 2019). Acidity profile and power $\left(p K_{a}\right)$ are an essential factor to reflect a good silage fermentation. There was a significantly decrease in the $\mathrm{pH}$ value in S-silages in comparison to that of C-silages throughout the research (Figure 2). The outcomes of the current study were in line with $\mathrm{Li}$ et al. (2014), who found significant influence of sucrose addition on $\mathrm{pH}$ value. The addition of sucrose in silage leads to a higher availability of WSC (Kung et al., 2018), which may have positive effects on the $\mathrm{pH}$ value of silage, increasing the $\mathrm{LAB}$ number and improving the $\mathrm{LAB}$ growth. Lower $\mathrm{pH}$ value due to increased LAB population by supplementation of sucrose contributed to higher Flieg point (Figure 2). A strong linear relationship between Flieg point and silage quality has been identified in previous results (Toruk and Kayışlığlu, 2008; Turan and Önenç, 2018). Flieg point was positively correlated with 
dry matter; whereas, it was negatively correlated with $\mathrm{pH}$ value of silage (Gümüss et al., 2020). This theory might be supportive of the present study, namely increased DM in silage treated with sucrose, where the values ranged from $28.31 \%$ and $28.42 \%$ of DM at d 60 of ensiling. RFV has been commonly used by the United States to determine the feed value of alfalfa. Sucrose additive significantly increased RFV at d 7 and 14 of ensiling; however, it was unaffected at d 30 and 60 of ensiling (Figure 3). These outcomes were in line with the results of reported by Baba et al. (2018) that the addition of molasses to the silages improved RFV. Importantly, positive effects were stated with addition of silage additives to alfalfa silage. Supplemented sucrose in silage has been indicated to be advantageous due to increased silage WSC density (Kung et al., 2018), reduced $\mathrm{NH}_{3}-\mathrm{N}$ content by reducing breakdown of protein, (Gümüş et al., 2020), and improved LAB growth and number.

\section{Conclusion}

The addition of sucrose improved the silage quality and affected fermentation profile and relative feed value of alfalfa silage. Silages treated with sucrose were well in color, aromatic scent, and good structure compared to control. Lower $\mathrm{pH}$ value and higher Flieg point and RFV were observed in silages treated with sugar. This research showed the positive effects of sucrose addition on silage quality.

\section{References}

Aktürk B., Gümüş H. 2020. Effects of lactic acid bacteria inoculant on quality, fermentation profile and nutritive value of alfalfa silage at different ensiling period. Ankara Üniversitesi Veteriner Fakültesi Dergisi 37, 281-287

Baba, M., Nasir, A., Kabiru, A., Umar, G. A. 2018. Effects of additives and their levels of inclusion on nutritive value of silage made from elephant grass (Pennisetum purpureum). Nigerian Journal of Animal Production 45(2), 352-362.

Dawson, B., Trapp, R.G. 2001. Basic and clinical biostatistics. 3rd ed., Lange 305 Medical Books/ McGraw-Hill Medical Publishing Division, New York, USA, 89, 306 131-153.
DLG, 1997. DLG-Schlussel zur Beurteilung der Garqualita " $t$ von Grunfuttersilagen auf der Basis der chemischen Untersuchung. [DLG-pattern for the Evaluation of the Fermentation Quality of Grass Silages on the basis of Chemical Analyses]. Frankfurta. M.: Deutsche Landwirtschafts-Gesellschaft.

Dong, Z., Yuan, X., Wen, A., Desta, S. T., Shao, T. 2017. Effects of calcium propionate on the fermentation quality and aerobic stability of alfalfa silage. Asian-Australasian Journal of Animal Sciences 30(9), 1278.

Ergin S., Gümüş H. 2020. Silage quality, fermentation dynamics and chemical composition of alfalfa silage prepared with salt and lactic acid bacteria inoculants. Animal Nutrition and Feed Technology 20, 367-380

Gao, R., Wang B., Jia T., Luo Y., Yu Z. 2021. Effects of different carbohydrate sources on alfalfa silage quality at different ensiling days. Agriculture 11(1), 58.

Gümüş, H., Oğuz, F.K., Oğuz, M.N., Buğdaycı, K.E., Kuter, E. 2020. The Effects of Different Additives on the Fermentation and Physical Characteristics of Lenox Silage. Journal of Faculty of Veterinary Medicine, Erciyes University 17, 39-44.

Kung Jr, L., Shaver, R.D., Grant, R.J., Schmidt, R.J. 2018. Silage review: Interpretation of chemical, microbial, and organoleptic components of silages. Journal of Dairy Science 101(5), 4020-4033.

Li, M., Zi, X., Zhou, H., Hou, G., Cai, Y. 2014. Effects of sucrose, glucose, molasses and cellulase on fermentation quality and in vitro gas production of king grass silage. Animal Feed Science and Technology 197, 206-212.

Muck, R.E., Nadeau, E.M.G., McAllister, T.A., Contreras-Govea, F.E., Santos, M.C., Kung Jr, L. 2018. Silage review: Recent advances and future uses of silage additives. Journal of Dairy Science 101(5), 39804000 .

Ni, K., Wang, F., Zhu, B., Yang, J., Zhou, G., Pan, Y., Tao, Y. and Zhong, J. 2017. Effects of lactic acid bacteria and molasses additives on the microbial community and fermentation quality of soybean silage. Bioresource Technology 238, 706-715.

Patra, S.P, Paul T. 2019. Lucerne. In: Hedayetullah M., Zaman P. (Eds.), Forage Crops of the World. Apple Academic Press, Canada, pp. 231-243

Redfearn, D., Zhang, H., Caddel, J. 2014. Forage Quality Interpretations. Oklahoma Cooperative Extension Service, PSS-2117. Available at http://factsheets.okstate.edu/ (Accessed October 2, 2021). 
Topçu, G.D., Özkan, S.S. 2021. Quality properties of sunn hemp (Crotalaria juncea L.) and maize (Zea mays L.) silages. Tropical Grasslands-Forrajes Tropicales 9(3), 315-320.

Toruk, F., Kayişoğlu, B. 2008. Effect of applied vacuum of silage package machine on silage quality. Journal of Agricultural Mach Sciences 4, 355-60.

TUIK. 2020. Turkish Statistical Institute. www.tuik.gov.tr. (Erişim 17.10.2021)

Turan A., Önenç S.S. 2018. Effect of cumin essential oil usage on fermentation quality, aerobic stability and in vitro digetibility of alfalfa silage. Asian-Australasian Journal of Animal Sciences 31, 1252-1258.

Unal, Y.S., Deniz, A., Toros, H. and Incecik, S. 2012. Temporal and spatial patterns of precipitation variability for annual, wet, and dry seasons in Turkey. International Journal of Climatology 32, 392-405.

Yan, Y., Li, X., Guan, H., Huang, L., Ma, X., Peng, Y., Li, Z., Nie, G., Zhou, J., Yang, W., Cai, Y. and Zhang, X. 2019. Microbial community and fermentation characteristic of Italian ryegrass silage prepared with corn stover and lactic acid bacteria. Bioresource Technology 279, 166-173.

Zhao, J., Dong, Z., Li, J., Chen, L., Bai, Y., Jia, Y., Shao, T. 2019. Effects of lactic acid bacteria and molasses on fermentation dynamics, structural and nonstructural carbohydrate composition and in vitro ruminal fermentation of rice straw silage. AsianAustralasian Journal of Animal Sciences 32(6), 783. 